\title{
EVALUATION OF THE SURFACE SETTLEMENT ABOVE THE PRAGUE METRO LINE A EXTENSION CONSTRUCTED BY TWO SHIELDS
}

\author{
Matouš Hilar $^{a, b, *}$, Nhu The TuAN ${ }^{a}$ \\ ${ }^{a}$ Faculty of Civil Engineering, Czech Technical University in Prague, Thákurova 7, 166 29 Prague, Czech \\ Republic \\ ${ }^{b}$ 3G Consulting Engineers s.r.o. Na Usedlosti 16, 14700 Prague, Czech Republic \\ * corresponding author: hilar@3-g.cz
}

ABstract.

The new section of the Prague metro V.A is located in the west part of Prague, between stations Dejvická and Motol Hospital. The new metro section is $6.2 \mathrm{~km}$ long and has four new stations. Majority of the two running tunnels that are $6.2 \mathrm{~km}$ long were excavated by two EPB (Earth Pressure Balance) shields $(2 \times 4.8 \mathrm{~km})$, it was the first use of modern tunnelling machines in the Czech Republic. Surface settlement above the running tunnels caused by the EPB shields was regularly monitored. The following paper is focused on an evaluation of the mentioned surface settlement using a volume loss. Consequently, numerical modelling of various cross-sections was executed. Modelling was realised by a finite element method in 2D, using the software Plaxis. Two different approaches were applied for modelling of the $3 \mathrm{D}$ effect in $2 \mathrm{D}$. Important parameters $M_{\text {stage }}$ and $C_{\text {ref }}$ were derived for the selected cross-sections by back analyses (comparison of the numerical modelling results with the results of monitoring). The results of realised numerical modelling and the volume loss evaluation can be used for a preparation and realisation of similar tunnels in similar geology (for example, construction of the Prague metro line D, which will probably also be excavated by the EPB shields).

KEYWORDS: numerical modelling; tunnel; mechanical excavation; monitoring; settlement.

\section{INTRODUCTION}

The new section of the Prague metro V.A (Figure 1) is located in the west part of Prague between the stations Dejvická and Motol Hospital [2-4]. The new metro section is $6.2 \mathrm{~km}$ long and has four new stations. Three stations were mined using the New Austrian Tunnel Method (NATM) (stations Bořislavka, Veleslavín, and Petrriny), one station was constructed from the surface by the Cut and Cover method (station Motol Hospital) [9, 10. Two single-track running tunnels from Vypich to Dejvická $(2 \times 4.8 \mathrm{~km})$ were excavated by the two EPB shields, it was the first use of modern tunnelling machines in the Czech Republic [17]. All NATM stations were constructed prior to the arrival of the EBP shields. One double-track running tunnel between the Motol Hospital and the Vypich was excavated by the NATM.

Both EPB shields were manufactured by the German company Herrenknecht (Figure 2, 1, 6, 7]. They have a diameter of $6 \mathrm{~m}, 8 \mathrm{~m}$ in length and the length of gantries is $80 \mathrm{~m}$. The principle of driving tunnels by the EPBM machines is based on disintegrating the ground at the tunnel face by the cutting tools installed on the rotating cutter head. Then, the disintegrated ground goes through the openings in the cutting head to the extraction chamber, where it is mixed with the previously disintegrated ground. Force induced by hydraulic jacks, which are supported by a segmen- tal tunnel lining, is transmitted to the disintegrated muck by the means of a pressure partition. With the back-pressure secured, pressure partition prevents uncontrolled intrusion of muck from the tunnel face to the machine, stabilizes the tunnel face wall and prevents the risk of an overbreak. Then, the muck is transported by a screw conveyor from the chamber. Segmental lining is installed by an erector after the completion of the excavation cycle. Segmental lining of the Prague metro V.A [5, 11] has an internal diameter of $5.3 \mathrm{~m}$, a thickness of $250 \mathrm{~mm}$, the length of rings is $1.5 \mathrm{~m}$ and each ring has 6 segments (including key segment). The annulus between the segmental lining and the excavated profile in the ground is grouted.

\section{Evaluation of REALised SURFACE SETTLEMENT AND VOLUME LOSS}

The surface settlement control is a very important feature of each tunnelling project, especially in urban areas. The maximum settlement above the running tunnels of the metro V.A was limited to the value of $10 \mathrm{~mm}$. Approximately first $4.8 \mathrm{~km}$ of the running tunnels were excavated by the EPB shields in a rock with an overburden of $20-30 \mathrm{~m}$, excavation in the open mode was used in the first part. Unfortunately, the remaining $1.8 \mathrm{~km}$ had to be excavated under the Evropská Street with an overburden of $12-16 \mathrm{~m}$ in a soft ground with the water table $6 \mathrm{~m}$ above the tunnel 


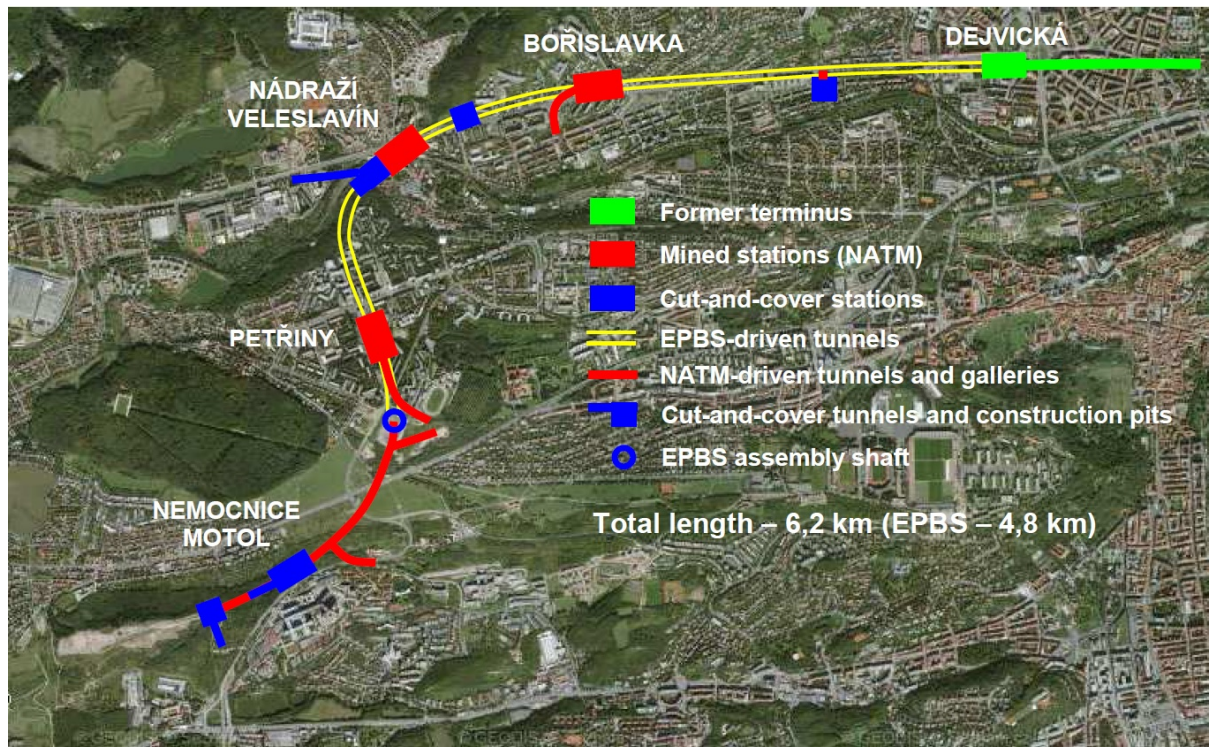

Figure 1. Situation of Prague metro V.A (running tunnels excavated by EPB shields are yellow) [20].

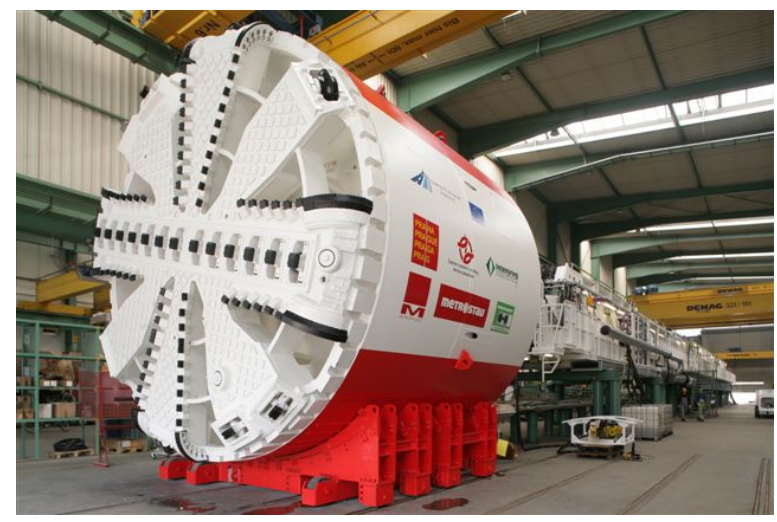

Figure 2. EPB shield for Prague metro V.A manufactured in Germany.

crown. The settlement control in the second part was more difficult, the excavation in the close mode had to be used in some areas.

All monitoring data, including the surface settlement, were recorded to the system BARAB available online for all participants involved in excavations. The maximal settlement monitored after the excavation of both running tunnels on the tunnel section from $\mathrm{km} 11.4$ to $\mathrm{km} 16.2$ are presented in Figure 3 [18.

The presented monitoring results correspond with the geology and the overburden. Favourable settlement results were recorded in the section from km 11.470 (Vypich) to km 14.522 (Bořislavka), where the monitored settlement generally stayed below the prescribed $10 \mathrm{~mm}$, the maximal settlement in this section was $16 \mathrm{~mm}$. Quite interesting are the recorded

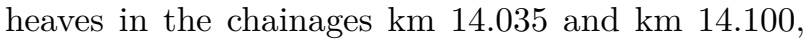
caused by a higher pressure of the EPB shields that were working in the close mode. Less favourable settlement results were recorded in the section from $\mathrm{km} 14.522$ (Bořislavka) to $\mathrm{km} 16.170$ (Dejvická), where the monitored settlement was from $3 \mathrm{~mm}$ to
$33 \mathrm{~mm}$. The higher settlement values were accepted by all involved parties as they did not caused any problems to the surface structures (tram railways, roads, etc.).

The volume loss 19 is an important parameter for the evaluation of the tunnelling activities, as this value gives some picture about the quality of the tunnelling. It can be calculated by the following equation:

$$
V_{\mathrm{L}}=\frac{\Delta A}{A} \cdot 100 \%,
$$

where $V_{\mathrm{L}}$ is the volume loss (\%), $\Delta A$ is the area of the settlement crater on the surface $\left(\mathrm{m}^{2}\right)$ and $A$ is the area of excavated profile $\left(\mathrm{m}^{2}\right)$.

Values of the volume loss for EPB shields generally stay between 0.2 and $0.5 \%$, the volume loss for the conventional tunnelling (NATM or SCL) is generally higher.

Monitoring results from the BARAB system were used for the volume loss evaluation. The evaluation was realised on 35 cross sections. The settlement of all cross section was drawn in AutoCad and areas of settlement craters were calculated, volume loss values were calculated afterwards. Volume loss results, together with settlement results, are presented in Figure 4.

Acceptable values of the volume loss were recorded in the first part of the excavations in the chainage

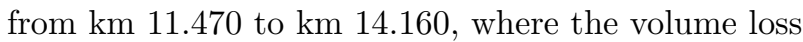
values generally stayed below $0.5 \%$. The recorded volume loss was very good, namely in the section from $\mathrm{km} 13.960$ to $\mathrm{km} 14.160$, where values close to 0 were recorded. The volume loss values in the section from $\mathrm{km} 14.520$ (Bořislavka) to km 16.170 (Dejvická) are more problematic, the worst value of $1.85 \%$ was recorded at the chainage $\mathrm{km} 14.583$.

The monitored settlement was affected by various reasons, especially by geological and hydrogeological conditions and by the applied modes of the EPB 


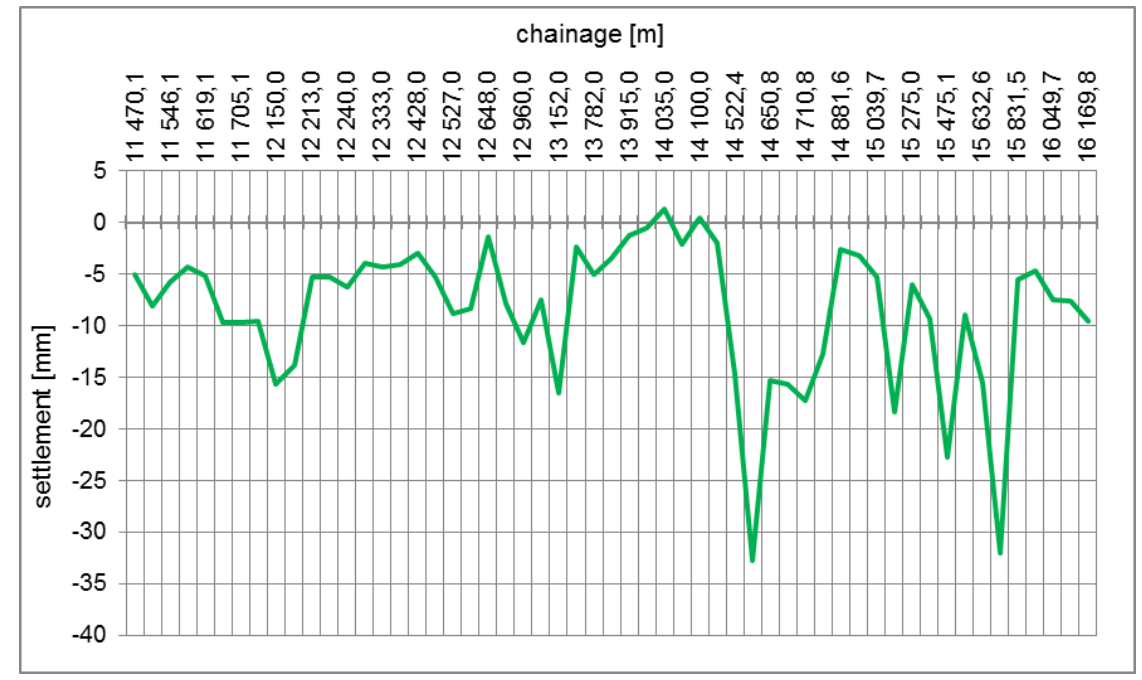

Figure 3. The maximal surface settlement monitored after the excavation of both running tunnels on the tunnel section from $\mathrm{km} 11.4$ to $\mathrm{km} 16.2$.

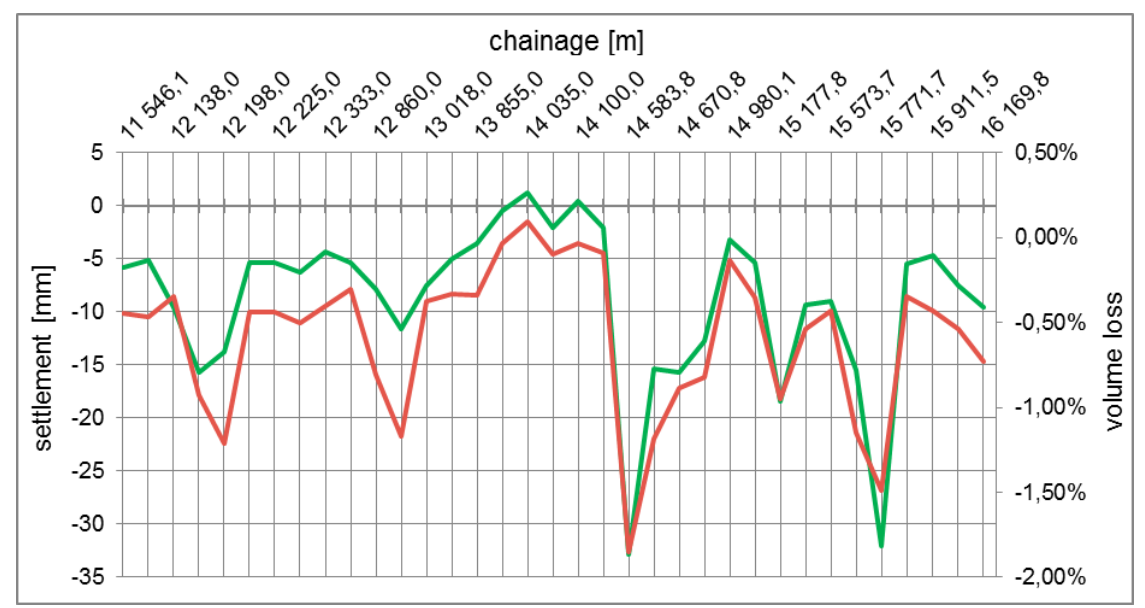

FiguRE 4. Maximal settlement (green colour) and calculated volume loss (red colour).

\begin{tabular}{lcc}
\hline & Chainage & Overburden \\
\hline Cross-section 1 & $14.583 \mathrm{~km}$ & $16.5 \mathrm{~m}$ \\
Cross-section 2 & $15.040 \mathrm{~km}$ & $15.2 \mathrm{~m}$ \\
Cross-section 3 & $15.632 \mathrm{~km}$ & $13.3 \mathrm{~m}$ \\
\hline
\end{tabular}

TABLE 1. Cross-sections selected for numerical modelling.

shields (open mode and close mode). The close mode with the full support of the tunnel face was applied under the residential complex Hvězda (chainage km 12.212.4) and under the tower buildings of the Cervený Vrch area (chainage km 13.7-14.1). The close mode application was used due to worries about the stability of buildings and the results of the monitoring confirmed the benefits of the decision about close mode, as the monitored settlement was very low (generally below $5 \mathrm{~mm})$.

The close mode was also applied under the Evropská street between the stations Bořislavka and Dejvická. But excavations in this section were affected by a low overburden with some voids, which had to be filled in advance by grouting. Major settlement was recorded especially at the interactions of shales $\left(26 \mathrm{kN} / \mathrm{m}^{3}\right)$ with deluvial sediments $\left(19 \mathrm{kN} / \mathrm{m}^{3}\right)$ due to their different density, which negatively affected the tunnel face support controlled by the weight of the excavated muck.

\section{NumERICAL MODELLING}

Three cross-sections of the Prague metro V.A were evaluated by the numerical modelling (Table 1). All selected cross-sections are situated below the Evropská street between the stations Bořislavka and Dejvická. All selected cross-sections are situated close to boreholes, thus geological and geotechnical data were available. All elected cross-sections were monitored by the surface levelling. The spacing of the cross-sections is about $500 \mathrm{~m}$. Numerical modelling was done by a finite element method in $2 \mathrm{D}$ using the software Plaxis [12, 14, 15.

An extensive site investigation was realised prior to the start of the construction. The realised site 


\begin{tabular}{|c|c|c|c|c|c|c|}
\hline \multicolumn{2}{|c|}{ Ground } & $\begin{array}{c}\text { Unit } \\
\text { weight }\end{array}$ & $\begin{array}{c}\text { Modulus of } \\
\text { deformation }\end{array}$ & $\begin{array}{c}\text { Poisson's } \\
\text { ratio }\end{array}$ & \multicolumn{2}{|c|}{$\begin{array}{c}\text { Effective shear } \\
\text { parameters }\end{array}$} \\
\cline { 2 - 7 } & $\gamma\left[\mathrm{kN} / \mathrm{m}^{3}\right]$ & $\mathrm{E}_{\text {def }}[\mathrm{MPa}]$ & $v[-]$ & $\varphi_{\text {ef }}\left[^{\circ}\right]$ & $\mathrm{C}_{\mathrm{ef}}[\mathrm{kPa}]$ \\
\cline { 2 - 7 } GT1 - An & $\begin{array}{c}\text { Anthropogen } \\
\text { ic backfill }\end{array}$ & 19.5 & 8 & 0.4 & 20 & 10 \\
\hline GT2 - Qe & $\begin{array}{c}\text { Eolian } \\
\text { sediments }\end{array}$ & 20.0 & 10 & 0.35 & 23 & 12 \\
\hline GT3 - Qd & $\begin{array}{c}\text { Deluvial } \\
\text { sediments }\end{array}$ & 19.0 & 15 & 0.35 & 25 & 15 \\
\hline $\begin{array}{c}\text { GT4 - } \\
\text { Qf* }\end{array}$ & $\begin{array}{c}\text { Fluvial } \\
\text { sediments }\end{array}$ & 18.5 & 6 & 0.35 & 20 & 10 \\
\hline $\begin{array}{c}\text { GT5 - } \\
\text { OBe }\end{array}$ & $\begin{array}{c}\text { Shales - } \\
\text { decomposed }\end{array}$ & 22.5 & 20 & 0.30 & 23 & 25 \\
\hline $\begin{array}{c}\text { GT6 - } \\
\text { OBz }\end{array}$ & $\begin{array}{c}\text { Shales - } \\
\text { partly } \\
\text { weathered }\end{array}$ & 25.5 & 70 & 0.28 & 25 & 35 \\
\hline $\mathbf{G T 7}$ - & $\begin{array}{c}\text { Shales - } \\
\text { OBw }\end{array}$ & 24.5 & 225 & 0.25 & 40 & 70 \\
\hline
\end{tabular}

TABLE 2. Geotechnical parameters of encountered layers applied for numerical modelling

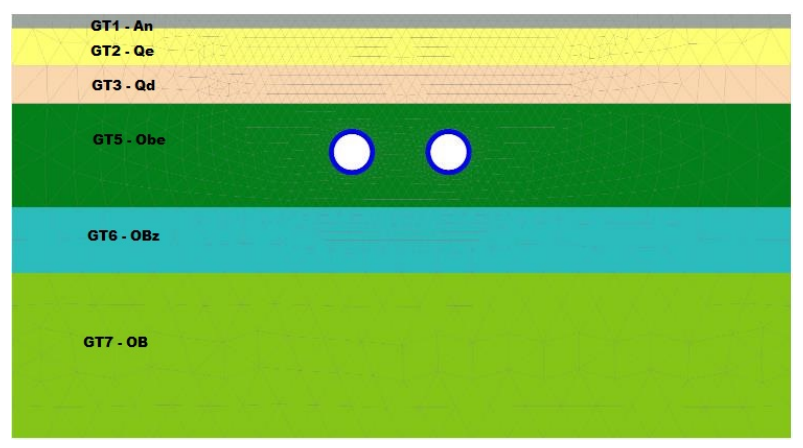

Figure 5. Model of the cross-sections km 14.583.

investigation had several stages, various methods were used in various stages. Geotechnical parameters of the encountered layers and the position of layers in various cross-sections were based on all available data (i.e. information from archives, boreholes, pits, documentation of outcrops, laboratory testing of soils and rocks, field methods, geophysical methods, etc.). Geotechnical parameters recommended by the authors of the realised site investigation and applied for the realised numerical modelling are summarised in Table 2 Dilatancy was assumed to be zero for all layers (as recommended by the realised site investigation). Effective shear parameters and drained conditions were applied for the numerical modelling (a rapid redistribution of pore pressures). Stages of the numerical modelling included water table lowering during the excavation in the open mode and its return after the impermeable tunnel lining installation.

A similar geometry of modelled areas $(100 \mathrm{~m}$ wide and $60 \mathrm{~m}$ high) was used for all cross-sections. The position of geotechnical layers and the overburden of tunnels are shown in Figures 5 7. Pillar between tunnel tubes is $7 \mathrm{~m}$. The modelled position of the water table corresponds with the results of the site investigation (3-4 $\mathrm{m}$ above tunnels). Horizontal in situ stress was calculated from vertical in situ stress $\sigma_{\mathrm{h}, \mathrm{ef}}=\sigma_{\mathrm{v}, \mathrm{ef}} K_{0}$. The coefficient of the lateral pressure

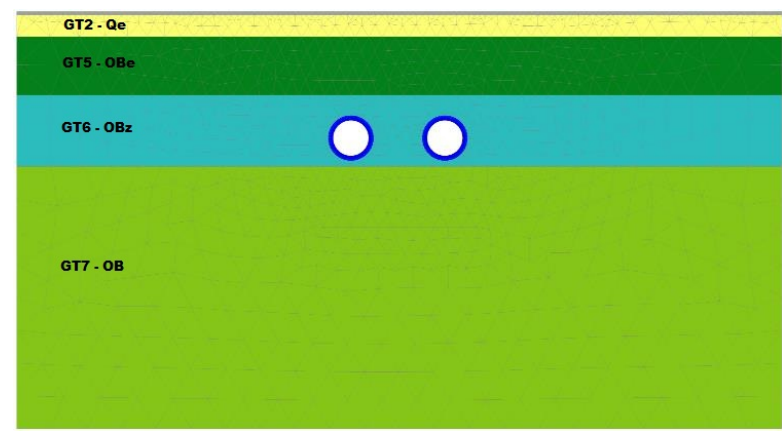

FiguRE 6. Model of the cross-sections km 15.040.

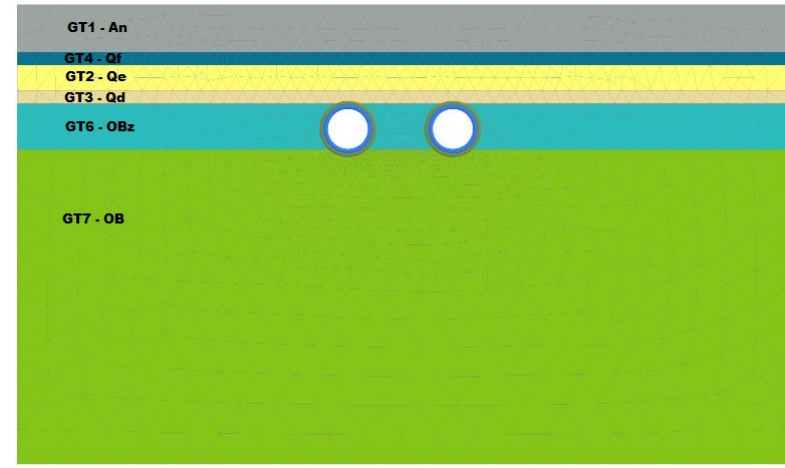

Figure 7. Model of the cross-sections km 15.632.

at rest $K_{0}$ was determined according to the formula of Jaky $K_{0}=1-\sin \varphi_{\text {ef }}$. No overconsolidation was recorded by the site investigation.

Models include both tunnel tubes. A tunnel lining generated from the precast concrete segments, which are $250 \mathrm{~mm}$ thick, was modelled by beam elements as a circular lining with a diameter of $5.8 \mathrm{~m}$ (external diameter of the segmental lining). Phases of the tunnel construction were modelled using two approaches [13]:

Variant A ( $\beta$ method), see Figure 8

(1.) initial stress;

(2.) excavation and its partial load;

(3.) tunnel lining installation and its full load. 

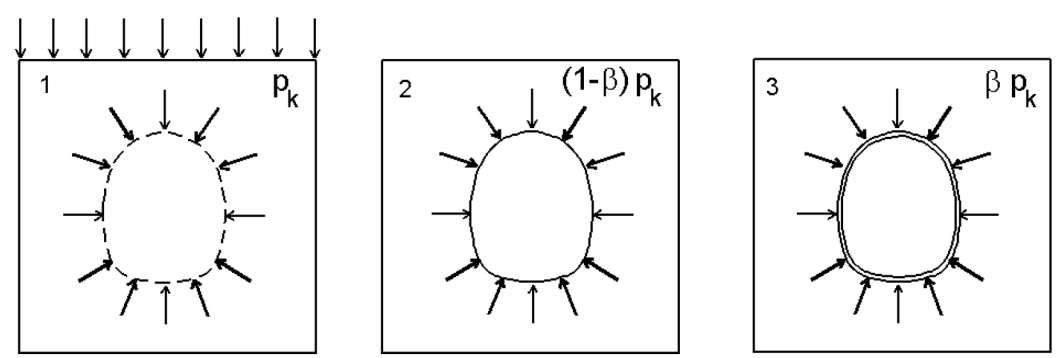

FiguRE 8. Schematic illustration of the $\beta$ method.

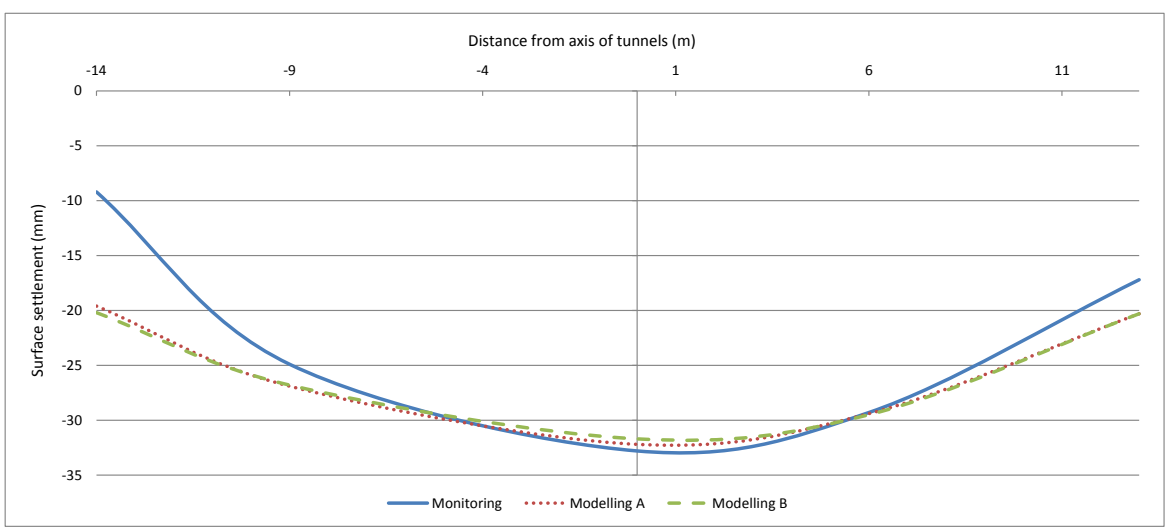

FiguRE 9. Cross-section km 14.583 - comparison of monitored and calculated settlement.

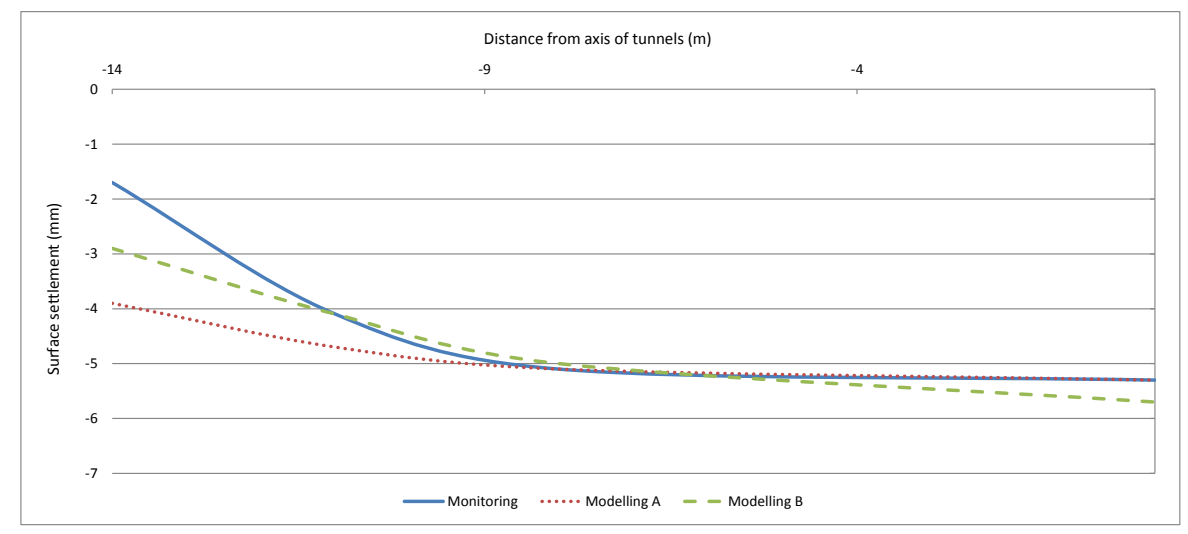

FiguRE 10. Cross-section km 15.040 - comparison of monitored and calculated settlement.

Variant B (contraction):

(1.) initial stress;

(2.) excavation and tunnel lining installation;

(3.) tunnel lining contraction.

The first one, Variant A, is generally used for the NATM tunnels, the stress redistribution in a ground is simulated using the $\beta$ method (partial load of an unsupported excavation). The second one, Variant $\mathrm{B}$, can only be used for circular profiles, thus it is recommended for the TBM tunnels. The stress redistribution in a ground for the Variant B is simulated using the contraction (reduction of the tunnel lining profile after its activation). Problem of the Variant A is the correct determination of the coefficient $M_{\text {stage }}$ (part of the load applied for the unsupported exca- vation $\left.(1-\beta) p_{\mathrm{k}}\right)$, problem of the Variant $\mathrm{B}$ is the correct determination of the contraction $C_{\text {ref }}$. Both coefficients were determined by the back analyses. The comparison of the monitored and modelled surface settlement and the relevant coefficients $M_{\text {stage }}$ and $C_{\text {ref }}$ for modelled cross-sections are shown in Figures 9011

The results of the realised numerical modelling are interesting. The variation of the required coefficient $M_{\text {stage was not too high (Table 3), required coefficients }}$ $M_{\text {stage }}$ are within the interval generally recommended for the NATM tunnels (from 0.3 to 0.5 ). The variation of required coefficients $C_{\text {ref }}$ was significantly higher. The original assumption that the values of the required coefficients $C_{\text {ref }}$ should be equal to the monitored volume loss was not confirmed, but a certain relation was confirmed (i.e. for higher volume loss $V_{\mathrm{L}}$ higher $C_{\text {ref }}$ is required). 


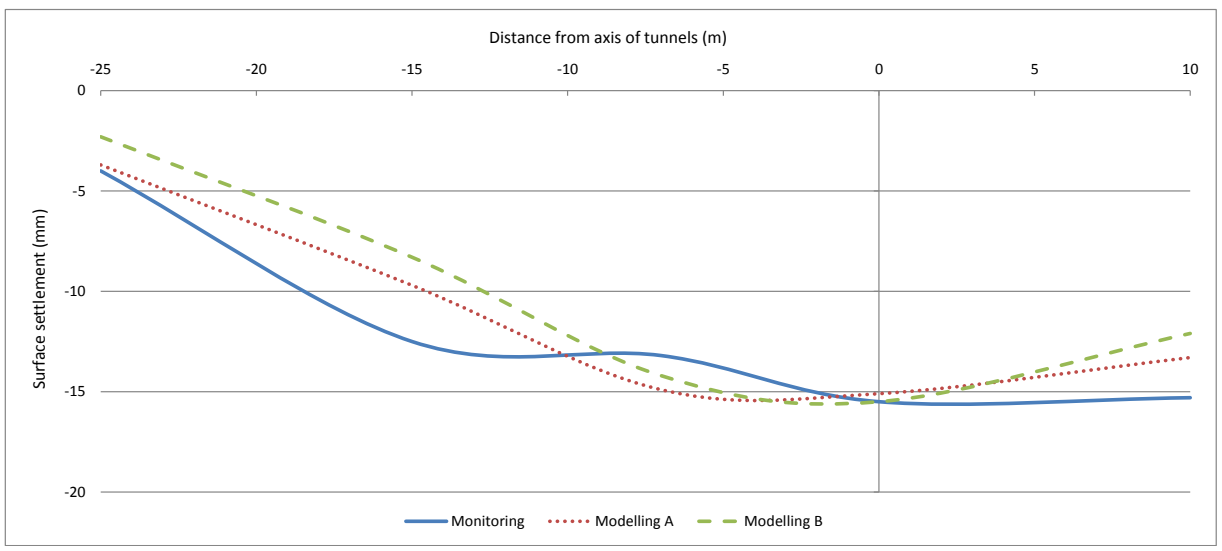

FiguRE 11. Cross-section km 15.632 - comparison of monitored and calculated settlement.

\begin{tabular}{lccccc}
\hline & Chainage & Monitored surface settlement & $V_{\mathrm{L}}$ & $C_{\text {ref }}$ & $M_{\text {stage }}$ \\
\hline Cross-section 1 & $14.583 \mathrm{~km}$ & $32.8 \mathrm{~mm}$ & $1.8 \%$ & $3 \%$ & 0.36 \\
Cross-section 2 & $15.040 \mathrm{~km}$ & $5.3 \mathrm{~mm}$ & $0.1 \%$ & $0.6 \%$ & 0.35 \\
Cross-section 3 & $15.632 \mathrm{~km}$ & $15.5 \mathrm{~mm}$ & $0.5 \%$ & $1.05 \%$ & 0.46 \\
\hline
\end{tabular}

TABLE 3. Comparison of required coefficients $C_{\text {ref }}$ and $M_{\text {stage }}$ for modelled cross-sections.

\section{Conclusions}

The excavation of the Prague metro A by the two modern EPB shields was generally successful. The speed of the excavations was generally high, the maximum progress per month was $627 \mathrm{~m}$, the maximum progress per day was $33 \mathrm{~m}$. The monitored surface settlement along the alignment generally stayed below the required $10 \mathrm{~mm}$, but some monitored values were higher (up to $33 \mathrm{~mm}$ ). Acceptable values of the volume loss were recorded in the first part of the excavations in the chainage from $\mathrm{km} 11.470$ to $\mathrm{km} \mathrm{14.160,} \mathrm{where} \mathrm{the}$ volume loss values generally stayed below $0.5 \%$. The recorded volume loss was very good namely in the sec-

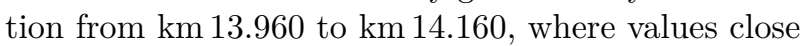
to 0 were recorded. Volume loss values in the section from $\mathrm{km} 14.520$ (Bořislavka) to km 16.170 (Dejvická) are more problematic, the worst value of $1.85 \%$ was recorded at the chainage $\mathrm{km} \mathrm{14.583.} \mathrm{Realised} \mathrm{numer-}$ ical modelling of the three cross-sections served for the evaluation of the two variants of the modelling of excavations realised by the EPB shields (so called $\beta$ method and tunnel lining contraction). Important parameters $M_{\text {stage }}$ and $C_{\text {ref }}$ were derived for the selected cross-sections by the back analyses (a comparison of the numerical modelling results with the results of the monitoring). The realised modelling showed that the $\beta$ method is probably more appropriate, as the interval of the appropriate $M_{\text {stage }}$ parameter was not high (0.35-0.46) and generally stayed inside the recommended interval $(0.3-0.5)$. Interval of the appropriate contraction was higher $(0.6-3.0 \%)$ and it is quite difficult to determine $C_{\text {ref }}$ prior to the start of the excavation. Shapes of the calculated settlement craters reached with the Mohr-Coulomb model matched reasonably well with the monitored data, some more advanced models should be able to reach a better agreement. The realised site investigation proposed parameters only for the Mohr-Coulomb model, a derivation of parameters for other models would be complicated. Results of the realised numerical modelling and the volume loss evaluation can be used for preparation and realisation of similar tunnels in similar geology (for example, construction of the Prague metro line D, which will probably also be excavated by EPB shields).

\section{ACKNOWLEDGEMENTS}

Financial support from the TAČR grant TE01020168 is gratefully acknowledged.

\section{REFERENCES}

[1] Bäppler K.: Two Earth Pressure Balanced Shields for Metro Line A Extension of Prague Metro. Tunel 3/2011. ISSN 1211-0728

[2] Barták J., Hilar M., Pruška J.: Development of underground construction engineering in the Czech Republic. Geomechanics and Tunnelling 2/2013. Ernst \& Sohn. DOI:10.1002/geot.201300006

[3] Bartoň V., Cigánek V., Hasík O., Krása D., Kutil J.: Prague Metro Line A Extension - Design and Investment Preparation. Tunel 2/2010. ISSN 1211-0728

[4] Bartoň V., Růžička J.: Metro line A extension to Ruzyně airport. Tunel 4/2007. ISSN 1211-0728

[5] Beňo J., Hilar M.: Steel fibre reinforced concrete segments for tunnel linings - verification by extensive laboratory testing and numerical modelling. Acta Polytechnica 4/2013. ISSN 1210-2709

[6] Cyroň D., Hybský P., Ivor Š., Prajer J., Schiffauer F., Hasík O.: Driving Single-Track Tunnels of Prague Metro V.A Line by Earth Pressure Balance Sheilds. Tunel 3/2011. ISSN 1211-0728 
[7] Cyroň D., Hybský P., Rössler K., Ivor Š., Prajer J.: Driving Single-track Tunnels of Prague Metro V.A using Earth Pressure Balance Shields. Tunel 1/2013. ISSN 1211-0728

[8] Hilar M.: 3D Modelling of a Tunnel Re-excavation in Soft Ground. Acta Polytechnica 3/2011. ISSN 1210-2709

[9] Kochánek M., Korejčík J.: Mined Tunnels on Prague Metro Line VA. Tunel 3/2009. ISSN 1211-0728

[10] Korejčík J., Růžička J.: Mined tunnels on the metro line A extension. Tunel 4/2007. ISSN 1211-0728

[11] Kuňák J., Urbánková M., Urbánek T.: Metro V.A Structural Analysis of Segmental Linings of Tunnels Driven by EPB Shields. Tunel 4/2011. ISSN 1211-0728

[12] Kunc, K., Pruška, J., Barták, J.: Mathematical modelling of arch-shaped cut-and-cover structures. Proceedings of the 33rd ITA-AITES World Tunnel Congress - Underground Space - The 4th Dimension of Metropolises 2007. ISBN 978-0-415-40807-3

[13] Nhu The T.: Evaluation of EPB shield excavation impact on deformations of surrounding ground. Czech Technical University in Prague 2016

[14] Pruška, J., Vrbata, J. Application of latin hypercube sampling method in tunnel analyses. International
Multidisciplinary Scientific GeoConference Surveying Geology and Mining Ecology Management, SGEM, 2014 DOI:10.5593/sgem2014/b12/s2.013

[15] Pruška, J.: Analysis of input parameters of the rock mass. Proceedings of the 33rd ITA-AITES World Tunnel Congress - Underground Space - The 4th Dimension of Metropolises 2007 DOI:10.1201/noe0415408073.ch110

[16] Stehlík E.: Prague Metro construction - past, present and future. Tunel 1/2013. ISSN 1211-0728

[17] Šebesta B., Schiffauer F., Vítek P.: Tunnel Excavation Technology using Tunnelling Machines Returns to Prague Metro after 30 Years. Tunel 2/2010. ISSN 1211-0728

[18] Šlajs P.: Numerical modelling of the Prague metro V. A excavation. Czech Technical University in Prague 2015

[19] Thomas, A - Powell, D - Hilar, M.: The Role of numerical modelling in tunnel design. Tunel 1/2004. ISSN 1211-0728

[20] Tlamsa J., Ebermann T., Bohátka J., Bohátková L., Rout J.: Engineering Geological and Geotechnical Problems of the New Metro Line V.A Construction in Prague. Tunel 2/2012. ISSN 1211-0728 